anales de psicología / annals of psychology

2019, vol. $35, \mathrm{n}^{\circ} 3$ (october), 364-370

http://dx.doi.org/10.6018/analesps.35.3.329131
(C) Copyright 2019: Editum. Servicio de Publicaciones de la Universidad de Murcia. Murcia (Spain) ISSN print edition: 0212-9728. ISSN on line edition (http://revistas.um.es/analesps): 1695-2294.

On line edition License Creative Commons 4.0: BY-NC-ND

\title{
Functioning of psychopathy and trait aggression as predictive variables of criminal recidivism
}

\author{
Maria-Carmen Zabala-Baños ${ }^{1}$, Juan-José Criado-Alvárez², Olga López-Martinn ${ }^{1}$, Manuela Martínez-Lorca ${ }^{3}$, \\ Maria-Verónica Jimeno-Jiménez ${ }^{4,}$, and Jorge Javier Ricarte-Trives ${ }^{4}$
1 University of Castilla-La Mancha. Department of nursing, physiotherapy and occupational therapy. Faculty of occupational therapy, speech therapy and nursing. Talavera de la Reina, Toledo (Spain)
2 Integrated Care Management at Talavera de la Reina, Castilla-La Mancha Health Services, Talavera de la Reina, Toledo, Spain.
Department of Medical Sciences, School of Health Sciences, University of Castilla-La Mancha, Talavera de la Reina, Toledo (Spain).
3 University of Castilla-La Mancha. Department of Psychology. Faculty of occupational therapy, speech therapy and nursing. Talavera de la Reina, Toledo (Spain) 4 University of Castilla La Mancha. Department of Psychology, School of Medicine, Albacete (Spain)

\begin{abstract}
Título: Funcionamiento de la psicopatía y de la agresividad rasgo como factores implicados en la reincidencia delictiva.

Resumen: En el presente estudio se analizan varias medidas de agresivi dad y de psicopatía como posibles factores implicados en la reincidencia penitenciaria. Se obtuvieron datos sociodemográficos así como de agresividad y de psicopatía (CA, IPAS y TRIp) en una muestra de 110 varones internos de un centro penitenciario de Castilla-La Mancha (España). La muestra estuvo formada por dos grupos de 55 sujetos, caracterizados por presentar, o no, trastorno mental. Un $55.8 \%$ de los participantes eran reincidentes. La reincidencia mostró una asociación estadísticamente significativa $(p<0.05)$ con la mayoría de las dimensiones estudiadas de agresividad, con cifras superiores en esta variable en el grupo de reincidentes así como en el grupo de internos diagnosticados con trastorno mental. La variable que mejor predijo la probabilidad de reincidir fue la mezquindad psicopática. No se encontraron diferencias estadísticamente significativas entre la presencia de un trastorno mental y la reincidencia, aunque se observa que entre los reincidentes existe una mayor proporción de personas con un trastorno mental (63.6\%). Los reclusos con enfermedad mental presentan un mayor riesgo de reincidencia delictiva y ese riesgo está asociado a mayores puntuaciones en agresividad rasgo así como con mayores puntuaciones en desinhibición y mezquindad psicopática

Palabras clave: reincidencia; psicopatía; agresividad rasgo; enfermedad
\end{abstract} mental.

\section{Introduction}

Interest in the concept of recidivism has grown significantly in criminological research in recent years. The study of this concept aims to understand the criminological and psychosocial reality of individuals who, once identified as offenders, are sentenced, serve the corresponding sentence, and then repeat their previous criminal behaviors or engage in new types of offenses (King \& Elderbroom, 2014; Nakamura \& Bucklen, 2014). Under this perspective, criminal psychology has dedicated many decades to the study of recidivism with the aim of analyzing the processes of community re-entry and rehabilitation of offenders, the effectiveness of prison treatment programs and the preventive performance of recidivism risk assessment instruments, among other aspects (Bonta, Law, \& Hanson, 1998; Costopoulos, Plewinski, Monaghan, \& Edkins, 2017).

* Correspondence address [Dirección para correspondencia]

Maria-Verónica Jimeno-Jiménez. Department of Psychology, School of Medicine, University of Castilla La Mancha, Avda. Almansa 14, 02006 Albacete (Spain). E-mail: veronica.jimeno@uclm.es

(Article received: 14-10-2018; revised: 15-1-2019; accepted: 18-3-2019)
Abstract: This study analyzes several measures of aggression and psychopathy as possible factors involved in criminal recidivism. Sociodemographic data as well as aggression and psychopathy trait measures (CA, IPAS and TRIp) were obtained in a sample of 110 male inmates of a prison in Castilla-La Mancha (Spain). The sample consisted of two groups of 55 subjects, characterized by the presence or absence of mental disorder. A total of $55.8 \%$ of the participants were persistent offenders. Recidivism showed a statistically significant association $(p<0.05)$ with most of the dimensions studied for aggression, with higher scores on this variable in the group of reoffenders and in the group of inmates diagnosed with mental disorder. The variable that best predicted the likelihood of re-offending was psychopathic meanness. No statistically significant differences were found between the presence of a mental disorder and recidivism, although a greater percentage of recidivists presented a mental disorder $(63.6 \%)$. Inmates with mental illness have a higher risk of criminal recidivism and this risk is associated with higher scores in trait aggression as well as higher scores in disinhibition and psychopathic meanness

Keywords: recidivism; psychopathy; trait aggression; mental disorder.
The most widely used measure in empirical studies is criminal recidivism, re-entry to prison or re-imprisonment; including re-entry to prison for a new custodial sentence due to a failure to comply with standards of conduct, preventive imprisonment or the breach of a suspended sentence (Andres-Pueyo, 2015). Many of these studies analyze recidivism in relation to determinants and variables such as risk factors, treatment programs or personal variables, which provide more exact knowledge of recidivism to help design appropriate prevention and intervention strategies (AndresPueyo, 2015).

Although the comparison of recidivism rates at international level is complex due to factors such as differences in methodologies, follow-up times and criminal and prison laws, access to data across countries gives us a global vision of the scope of this phenomenon.

Few empirical studies on recidivism have been conducted in Spain, with the exception of the region of Catalonia, where a study on the prevalence of mental disorders in Spanish prisons (Vicens et al., 2011) reported that $54 \%$ of prisoners were re-offenders, and a report monitoring recidivism in Catalonia from 201 to 2013, which found a re-offending rate 
of $30.2 \%$ (various authors, 2015). In 2012, a study was conducted on criminal recidivism and published by the Ministry of the Interior (Graña, 2012). The study included a sample of 811 individuals and calculated the recidivism rate based on a detailed analysis of prison inmates with a criminal record. A total of $31.6 \%$ of the sample were reoffenders, of whom $10.1 \%$ had committed violent offenses and $8.5 \%$ sexual offenses. Subsequently, and replicating the study by Vicens et al., Zabala (2016) studied the relation between recidivism and mental disorder in a sample of 184 inmates, finding a criminal recidivism rate of $41.8 \%$.

In light of the above, it must be considered that the high rates of criminal recidivism in Spain have a significant impact, generating high social and economic costs. Hence, recidivism risk assessment represents an important challenge.

Regarding the predictors of recidivism, the findings of various studies focus on personal and socio-environmental variables, which, in many cases, precede the first arrest and should be taken into account when determining individuals with a high risk of recidivism (Andrews \& Bonta, 2006; Bertone, Domínguez, Vallejos, Muniello, \& López, 2013). Over recent decades, research has established a series of risk factors to determine the characteristics that identify individuals with a higher likelihood of reoffending. These factors are related to sociodemographic characteristics, criminal history, antisocial behavior, violence-linked attitudes, treatment adherence and presence of psychopathology, especially antisocial personality disorder (Rodríguez, Gómez, Fernández, \& Reyes, 2013; Yang, Wong, \& Coid, 2010). In addition, early substance abuse could be considered a "meta-variable" linked to other factors which trigger such behavior, including unemployment, a dysfunctional family environment, dropping out of school or lack of a social support network (Bertone et al., 2013; Håkansson \& Berglund, 2012). The complexity of analyzing these diverse variables corroborates the need for empirical studies that contribute to determine the relations between the different factors and their direct association with recidivism (Grann, Danesh, \& Fazel, 2008; Plattner et al., 2009).

With regard to aggressiveness, there is evidence that the frequency of past violent behaviors is a robust predictor of future violent conduct (Fazel, Buxrud, Ruchkin, \& Grann, 2010). In this sense, the literature also suggests an association between premediated aggression and psychopathy, as individuals with a personality disorder are characterized by insensitivity, manipulativeness and the use of interpersonal violence (Hare, 2003). A pioneering article published in 2015 (Swogger, Walsh, Christie, Priddy, \& Conner, 2015), using a one-year follow-up study of a cohort of offenders, compared impulsive and premeditated aggression as possible predictors of criminal recidivism. The findings indicated that premeditated, but not impulsive, aggression predicted violent reoffending, suggesting that assessment of the type of aggression may provide relevant information beyond the simple frequency of aggressive behaviors (Swogger, Walsh, Christie, Priddy, \& Conner, 2015).
Findings on the association between psychopathy and recidivism are inconsistent. Although a significant negative relationship has been found between the presence of components of psychopathology in offenders and the prediction of future criminal behaviors, an individual's criminal history has, however, been found to be the variable most strongly associated with criminal recidivism (Bonta et al.,1998; Costopoulos et al., 2017; Gendreau, Little, \& Goggin, 1996). Establishing a negative relationship between psychiatric diagnosis and recidivism would help mitigate the stigma surrounding persons with a mental health disorder and the supposed dangers inherent in their condition (Fazel \& Yu, 2011). However, it is important to note that other studies on the relationship between the presence of mental health problems and recidivism have found that inmates with a psychiatric disorder are more prone to reoffending and repeat incarceration compared with individuals with a psychiatric disorder but no previous incarceration (Baillargeon, Binswanger, Penn, Williams, \& Murray, 2009; Pflueger, Franke, Graf, \& Hachtel, 2015; Segeren, de Wit, Fassaert, \& Popma, 2017).

In view of the inconsistent findings in the previous literature, the aim of the present study is to shed some light on the role of factors such as psychopathy and aggression in criminal recidivism, with the hope of finding a positive association or results that contribute to the prediction of the risk of repeat offending, and the design of prevention and intervention strategies.

\section{Method}

\section{Participants}

The sample comprised 110 male inmates from a prison in Castilla-La Mancha (Spain), without neurological impairment, and aged between 16 and 65 years. It was divided into two groups of 55 participants, one consisting of inmates with mental disorder and the other of inmates with no mental health problems. The presence of substance use and psychopathology was diagnosed and supervised by the corresponding public mental health services. The participants had not committed their offenses under the influence of substance use.

\section{Instruments}

A questionnaire was administered on sociodemographic variables (age and educational level, among others), health variables (history of neurological damage, substance use and existence or absence of mental disorder) and criminal variables (reoffending, number of previous incarcerations and category of imprisonment). The recidivism data was collected using information taken from administrative records and provided by professional staff at the prison. This information on recidivism provided by the prison administration was used for the statistical analyses in the present study. Aggres- 
sion and psychopathy were measured using the three questionnaires described below.

Buss-Perry Aggression Questionnaire (BPAQ) (Buss\&Perry, 1992). This is one of the most widely used questionnaires for the assessment of aggression, which it measures across four dimensions: Physical Aggression, Verbal Aggression, Anger and Hostility. It comprises 29 items which respondents score on a scale ranging from 1 (never or almost never) to 5 (always or almost always).

The four dimensions showed adequate internal consistency in the sample used in this study: Physical Aggression (ordinal $\alpha=0.89$ ), Verbal Aggression (ordinal $\alpha=0.76$ ), Anger (ordinal $\alpha=0.81$ ), and Hostility (ordinal $\alpha=0.78$ ).

The Impulsive-Premeditated Aggression Scale (IPAS; Standford et al., 2003). This 30-item questionnaire collects information on the respondent's aggressive acts over the past six months. The items are rated on a five-point scale ranging from 1 (strongly disagree) to 5 (strongly agree). The scale measures three dimensions: Premeditated Aggression (e.g., "Some of the acts were attempts at revenge"), Impulsive Aggression (e.g., "I lost control of my temper during the acts"), and Familiarity with Target/Remorse (e.g., I knew most of the persons involved in the events). This study used only the first two subscales. Cronbach's alpha for these two factors were 0.89 and 0.84 , respectively.

Triarchic Psychopathy Measure (TriPM; Patrick \& Drislane, 2015). Based on the triarchic model of psychopathy proposed by Patrick et al. (2009), this questionnaire measures the dimensions of Disinhibition, Boldness and Meanness drawing on their relationship with the big five personality traits. These constructs are broken down into 24 facets, of which only three are used in this study: Empathy (e.g., How other people feel is important to me), Sensation Seeking (e.g., I would enjoy being in a high-speed chase) and Resiliency (e.g., I am wellequipped to deal with stress). The questionnaire comprises 58 items scored on a four-point scale where 4 is true, 3 mostly true, 2 mostly false, and 1 false. The ordinal alpha values for the triarchic model were 0.92 for Disinhibition, 0.73 for Boldness and 0.89 for Meanness.

\section{Procedure}

This project was approved by the Ethics Committee for Clinical Research of the corresponding health service area and the Secretariat General for Penitentiary Institutions of the Spanish Ministry of the Interior. The participants were informed that this was a study on aggressive experiences, and that confidentiality was ensured and no health risk was involved. Before the questionnaires were administered, the participants were provided with information about the general aims of the study. Once this information had been read, those who agreed gave their signed informed consent on the confidential treatment of the information obtained and its possible subsequent dissemination. The tests were individually administered in 30-45 minute sessions by an examiner who was previously trained to administer the instru- ments. The data collection was conducted in the prison infirmary.

\section{Statistical analysis}

For the descriptive analysis of the data, we used the descriptive parameters established in each specific scale. The Kolmogorov-Smirnov test was used to study the distribution of the data to a normal curve. The relationship between a continuous normal variable and a nominal variable was analyzed using ANOVA; if the outcome variable was dichotomous, the student's t-test was used. To compare nominal and dichotomous variables, we used the chi-squared test. In the multivariate logistic regression analysis, we calculated the association between the different variables and recidivism (dependent variable), implementing enter method logistic regression models. A confidence level of 0.05 was set. SPSS for Windows (Statistical Package Social Sciences version 15.0) was used for the data analysis.

\section{Results}

The study was conducted with 110 male prison inmates, of whom $55.8 \%(n=53)$ were reoffenders, and $77.2 \%(n=85)$ were under second-degree imprisonment. As regards the type of offense committed, the most frequent was robbery with violence, accounting for $30.5 \%$ of inmates $(n=29)$, followed by murder, $13.7 \%(\mathrm{n}=13)$, and homicide, $12.6 \%(n=$ 12). Most of the offenders were single or divorced, $48.6 \%$ ( $n$ $=53)$ and $16.5 \%(n=18)$, respectively, with no statistically significant differences between the reoffender and nonreoffender groups $\left(\chi^{2}=1.472, p=.689, g l=3\right)$.

Regarding education, the most common levels were primary $(58.2 \%)$ and secondary level $(31.8 \%)$, with no significant differences in the distribution of this variable between the two groups $\left(x^{2}=4.862, p=.182, g l=3\right)$.

Mean age was $M=41.4$, SD $=9.05$ years (Range: $24-69$ ) with statistically significant differences according to recidivism $(t=-2.219, p=.029, g l=93)$, and a difference of 4.1 years between non-reoffenders and reoffenders. Nonreoffenders had 7 years' more work experience than reoffenders $(t=-3.507, p=.001, g=89)$.

The inmates with mental disorder were aged $M=41.8$, $S D=9.54$ years, while those without mental disorder were aged $M=41.0, S D=8.60$ years. There were no significant differences between the groups $(t=-0.478, p=6.38, g l=$ 108).

A total of $50 \%(n=55)$ presented a mental disorder, but there was no statistically significant association with recidivism $\left(\chi^{2}=3.261, p=.071, g l=1\right)$. However, there was a higher proportion of participants with a mental disorder among reoffenders, $66 \%(n=35)$. No association was found with the type of pathology, given that the most frequent problem was personality disorders with $58.2 \%(n=32)$, followed by adaptive disorders, $23.6 \%(n=13)$, and psychotic disorders, $18.2 \%(n=10)$. The participants with mental di- 
sorder had received fewer years of schooling, $M=7.9, S D=$ 3.31 years, compared to $M=10.0, S D=3.10$ years for those without mental disorder TM $(t=3.312, p=.001, g l=107)$. The individuals with mental disorder presented a higher level of reimprisonment, $M=2.6, S D=1.66$, compared to those without a disorder, $M=1.9, S D=1.43(t=-2.122, p=.036$, $g l=93)$.
As regards the relationship between aggression and recidivism, we found statistically significant differences $(p<$ 0.05) in all the dimensions studied, with values being higher in the reoffender group, except for Boldness and Impulsive Aggression, where no significant differences were revealed (Table 1).

Table 1. Analysis of the differences (Student's t-test) in the study variables between reoffenders and non-reoffenders.

\begin{tabular}{|c|c|c|c|c|c|c|c|}
\hline & \multicolumn{4}{|c|}{ Recidivism } & \multicolumn{3}{|c|}{ Statistical significance } \\
\hline & \multicolumn{2}{|c|}{ No } & \multicolumn{2}{|c|}{ Yes } & \multirow{2}{*}{$t$} & \multirow{2}{*}{$P$} & \multirow{2}{*}{$g l$} \\
\hline & $M$ & $S D$ & $M$ & $S D$ & & & \\
\hline Physical Aggression & 19.3 & 6.96 & 25.3 & 8.85 & -3.528 & .001 & 89 \\
\hline Verbal Aggression & 10.4 & 3.63 & 13.8 & 4.06 & -4.128 & .000 & 9 \\
\hline Anger & 13.7 & 4.82 & 17.8 & 6.55 & -3.404 & .001 & 90 \\
\hline Hostility & 18.9 & 6.13 & 21.8 & 6.77 & -2.023 & .000 & 86 \\
\hline Boldness & 46.2 & 7.26 & 47.8 & 8.53 & -0.897 & .001 & 80 \\
\hline Meanness & 28.1 & 5.74 & 37.0 & 9.42 & -4.924 & .046 & 82 \\
\hline Disinhibition & 41.0 & 11.73 & 51.1 & 13.88 & -3.538 & .372 & 83 \\
\hline Premeditated Aggression & 23.8 & 7.36 & 28.7 & 8.45 & -2.889 & .000 & 88 \\
\hline Impulsive Aggression & 26.9 & 7.21 & 26.2 & 7.38 & 0.462 & .645 & 86 \\
\hline
\end{tabular}

The individuals with mental disorder presented similar results to those for recidivism, with statistically significant differences $(p<.05)$ in all the dimensions, and higher va-

lues in the mental disorder group, with the exception of Boldness, Verbal Aggression and Impulsive Aggression, where no significant differences were found (Table 2).

Table 2. Analysis of the differences (Student's t-test) in the mental disorder and aggression variables between reoffenders and non-reoffenders.

\begin{tabular}{|c|c|c|c|c|c|c|c|}
\hline & \multicolumn{4}{|c|}{ Mental Disorder } & \multicolumn{3}{|c|}{ Statistical significance } \\
\hline & \multicolumn{2}{|c|}{ No } & \multicolumn{2}{|c|}{ Yes } & \multirow{2}{*}{$t$} & \multirow{2}{*}{$p$} & \multirow{2}{*}{$g l$} \\
\hline & $M$ & $S D$ & $M$ & $M$ & & & \\
\hline Physical Aggression & 18.4 & 6.64 & 25.6 & 8.85 & -4.779 & .000 & 104 \\
\hline Verbal Aggression & 11.2 & 3.79 & 12.7 & 4.32 & -1.911 & .059 & 104 \\
\hline Anger & 13.0 & 4.59 & 18.3 & 6.22 & -4.946 & .000 & 105 \\
\hline Hostility & 18.0 & 6.00 & 23.3 & 5.89 & -4.458 & .000 & 101 \\
\hline Boldness & 47.3 & 6.93 & 46.8 & 9.18 & 0.304 & .762 & 95 \\
\hline Meanness & 30.9 & 7.62 & 35.6 & 10.18 & -2.631 & .010 & 96 \\
\hline Disinhibition & 41.1 & 10.07 & 52.2 & 14.19 & -4.550 & .000 & 97 \\
\hline Premeditated Aggression & 24.3 & 7.45 & 28.2 & 8.55 & -2.449 & .016 & 103 \\
\hline Impulsive Aggression & 25.6 & 6.38 & 27.5 & 7.66 & -1.362 & .176 & 101 \\
\hline
\end{tabular}

Of the reoffenders $(n=53), 63.6 \%$ had a mental disorder TM $(n=35)$. A total of $39.6 \%(n=21)$ of the individuals had been incarcerated twice, with a mean repeat incarceration rate of $M=3.3, S D=1.44$ (Range: $2-7$ ). There were significant differences between those with and without a mental disorder (Table 3). Statistically significant differences $(p<.05)$ can be observed for Physical Aggression, Anger, Hostility, Meanness and Disinhibition, with higher values in the mental disorder group.
The multivariate logistic regression analysis with recidivism as dependent variable revealed an Odds Ratio (OR) for meanness of 1.163 (IC 95\%: 1.078-1.254). In other words, the higher the level of meanness, the greater is the likelihood of reoffending (Table 4). This model predicts correctly in $71.4 \%$ of the cases, with the area under the ROC curve being $78.4 \%$ for the predicted values (IC 95\%: 68.7-88.1\%) $(p<$ $.05)$. 
Table 3. Aggression in reoffenders and mental disorder.

\begin{tabular}{|c|c|c|c|c|c|c|c|}
\hline & \multicolumn{4}{|c|}{ Mental Disorder } & \multicolumn{3}{|c|}{ Statistical significance } \\
\hline & \multicolumn{2}{|c|}{ No } & \multicolumn{2}{|c|}{$\mathrm{Si}$} & \multirow{2}{*}{$\mathrm{t}$} & \multirow{2}{*}{$p$} & \multirow{2}{*}{$g l$} \\
\hline & $\mathrm{M}$ & $\mathrm{SD}$ & $\mathrm{M}$ & $\mathrm{SD}$ & & & \\
\hline Physical Aggression & 19.5 & 8.11 & 28.2 & 7.81 & -3.691 & .001 & 49 \\
\hline Verbal Aggression & 12.7 & 4.01 & 14.4 & 4.02 & -1.457 & .152 & 48 \\
\hline Anger & 13.7 & 5.35 & 19.9 & 6.13 & -3.580 & .001 & 49 \\
\hline Hostility & 17.5 & 5.83 & 24.2 & 6.05 & -3.836 & .000 & 47 \\
\hline Boldness & 49.4 & 7.75 & 46.9 & 8.96 & 0.950 & .347 & 44 \\
\hline Meanness & 32.6 & 7.79 & 39.5 & 9.45 & -2.634 & .011 & 47 \\
\hline Disinhibition & 42.1 & 12.21 & 56.3 & 12.15 & -3.983 & .000 & 47 \\
\hline Premeditated Aggression & 25.8 & 6.54 & 30.2 & 9.01 & -1.756 & .085 & 49 \\
\hline Impulsive Aggression & 25.2 & 6.8 & 26.7 & 7.72 & -0.679 & .500 & 47 \\
\hline
\end{tabular}

Table 4. Variables in the logistic regression equation.

\begin{tabular}{|c|c|c|c|c|c|c|c|}
\hline & \multirow[t]{2}{*}{ B } & \multirow[t]{2}{*}{ SD } & \multirow[t]{2}{*}{ Wald } & \multirow[t]{2}{*}{$p$} & \multirow[t]{2}{*}{$\operatorname{Exp}(B)$} & \multicolumn{2}{|c|}{ IC $95.0 \%$ for $\operatorname{Exp}(B)$} \\
\hline & & & & & & Lower & Higher \\
\hline Meanness & 0.151 & 0.039 & 15.362 & .000 & 1.163 & 1.078 & 1.254 \\
\hline Constant & -4.510 & 1.225 & 13.548 & .000 & 0.01 & & \\
\hline
\end{tabular}

\section{Discussion}

The aim of this work was to determine the relationship between aggression, psychopathy and criminal recidivism in two groups of inmates, one with mental disorder and one without.

The sample comprised 110 male inmates proportionally divided into two groups according to presence or absence of mental disorder. The majority of the participants were sentenced for crimes against persons $26.3 \%$ for homicide or murder) with a criminal recidivism rate of $55.8 \%$. Few studies have been conducted in Spain on recidivism and mental disorder among prison inmates. The samples used present certain differences from that used in the present study since they were individuals who presented a series of risk factors increasing the likelihood of recidivism, linked to sociodemographic characteristics, criminal history, antisocial behavior, violence-related attitudes, treatment adherence and the presence of psychopathology, especially antisocial personality disorder (Rodríguez, Gómez, Fernández, \& Reyes, 2013; Yang, Wong, \& Coid, 2010).

Our study revealed no differences in criminal recidivism according to the presence or absence of mental illness; that is, recidivism was not associated with inmates suffering from mental disorder. This result coincides with the findings of Zabala (2016). The same result was also reported in studies conducted in other countries such as that by Hall, Miraglia, Lee, Chard-Wierschem and Sawyer (2012) on mentally ill persons leaving prison in New York State, which reported a similar risk of recidivism in inmates with and without mental disorder.

However, although we found no relationship between recidivism and mental disorder, our results did confirm a higher rate of repeat imprisonment among reoffenders with mental disorders compared to those without mental health problems. This coincides with previous works such as that by Cloyes et al. (2010), who conducted a study on Utah State prisoners with and without serious mental illness, finding that the median time to return to prison for prisoners with mental disorder was 3485 days, while for those without mental illness, this period was 743 days. Hence, persons with mental disorder reoffend sooner than those without, facilitating the higher number of repeat incarcerations among the former.

Personality disorders are the most common mental problem among the inmates in our study $(58.2 \%)$, although this percentage is lower than that reported in other studies conducted in Spain (López-Barrachina et al.; Vicens et al.,2011;2007; Zabala, 2016). Other studies have also focused on the analysis of the associations between recidivism and specific disorders. Zabala (2016), for example, reported that criminal recidivism was unrelated to personality disorders, while, Fazel and Yu (2011), found individuals with psychotic disorders presented a higher risk of reoffending compared to persons without mental disorder.

The analysis of the psychological variables under study showed that the reoffenders scored significantly higher on trait aggression, anger, hostility, physical and verbal aggression and premeditated aggression. With regard to the psychopathy factors, reoffenders scored higher on meanness and disinhibition. Meanness is the only psychological variables of the measures used in our research that predicted inmates' recidivism.

These findings partly coincide with those of a study conducted in Spain by the Forensic Science Institute of the Autonomous University of Madrid, which measured posttreatment criminal recidivism among intimate partner offenders between 2010 and 2015․ The study examined whether

${ }^{1}$ Reincidencia de los agresores de pareja en penas y medidas alternativas. Meritxell Pérez Ramírez, Andrea Giménez-Salinas Framis and Manuel de Juan Espinosa. Forensic Science Institute of the Autonomous University of Madrid. 
there existed pre-treatment differences in aggression between the reoffenders and non-reoffenders, finding higher levels of physical aggression in the reoffenders before the psychological intervention, but no differences in verbal aggression, anger and hostility. In addition, it is worth noting that in our study, the assessment of the psychological variables revealed the same results for inmates with mental disorder and reoffenders.

Finally, regarding the sociodemographic characteristics of the participants, the reoffenders were younger and had less work experience than the non-reoffenders, which highlights the need to focus attention also on individuals' personal circumstances before their first arrest in order to prevent recidivism (Andrews \& Bonta, 2006; Bertone, Domínguez, Vallejos, Muniello, \& López, 2013). In the case of inmates with mental disorder, we found that they had fewer years of schooling compared to those without disorder, coinciding with Zabala (2016), whose study found that prison inmates with mental disorder had low levels of education.

In conclusion, the presence of mental disorder is not a determinant of an inmate's likelihood of reoffending. However, inmates with a mental disorder do reoffend more frequently and score higher on all the aggression factors, as well as on disinhibition and meanness, with the latter being a predictor of recidivism.

The main limitations of our research lie in the sample. The sample size was small, there was a considerable age difference between the study groups (reoffenders and nonreoffenders), and the sample consisted only of male inmates, who were all incarcerated in the same prison. Thus, the lack of heterogeneity in our sample complicated a deeper study of recidivism according to the different mental disorders and types of offenses committed. Other difficulties we found were the diversity of the criteria for recidivism in this field, which complicates comparisons between studies at both national and international level, and the shortage of studies on recidivism and mental disorders, particularly studies including personality variables in the analysis of the inmates. We believe future research should tend towards further studies in Spain on criminal recidivism and psychopathologies, focusing in detail on the specific disorders that correlate with reoffending and including a larger number of personality variables in the study design, with the aim of improving recidivism prevention strategies.

In our opinion, the present work has important practical implications in the field of criminal psychology, as it identifies and analyzes measures of aggression and psychopathy involved in criminal recidivism, underlining the significance of the meanness variable in predicting prison inmates' likelihood of reoffending. This finding, we believe, is important because it opens up a new line of intervention in the search for solutions to the prevention of risk behaviors in this population. In addition, it is worth highlighting the importance of the sociodemographic variable of low educational level. Identifying these variables will facilitate the development of new methods of intervention, which can be implemented both in prisons, to prevent recidivism, and in schools, as a measure of primary prevention.

\section{References}

Andrés-Pueyo, A. (2015). Cuantos presos retornan a prisión Análisis y utilidad de los estudios de la reincidencia delictiva_APIF_2015.pdf. Boletin ATIP.

Andrews, D. A. y Bonta, J. (2006). The psychology of criminal conduct $\left(4^{\mathrm{a}}\right.$ ed.). Cincinnati, OH: Anderson Publishing.

Baillargeon, J., Binswanger, I. A., Penn, J. V., Williams, B. A., \& Murray, O. J. (2009). Psychiatric disorders and repeat incarcerations: The revolving prison door. American Journal of Psychiatry, 166(1), 103-109. http://doi.org/10.1176/appi.ajp.2008.08030416

Bertone, M. S., Domínguez, M. S., Vallejos, M., Muniello, J., \& López, P. L. (2013). Variables asociadas a la reincidencia delictiva. Psicopatología Clínica, Legal Y Forense, 13, 47-58.

Bonta, J., Law, M., \& Hanson, K. (1998). The Prediction of Criminal and Violent Recidivism Among Mentally Disordered Offenders: A Meta-Analysis. PSYCHOLOGICAL BULLETIN. Retrieved from http://explore.bl.uk/primo_library/libweb/action/display.do? tabs $=$ details Tab\&gathStat $\mathrm{Tab}=$ true $\& \mathrm{ct}=$ display $\& \mathrm{fn}=$ search $\& \mathrm{doc}=\mathrm{ET}$ OCRN613373549\&ind $\mathrm{x}=1 \& \mathrm{krecId}=\mathrm{ETOCRN} 040950886$

Cloyes, K. G., Wong, B., Latimer, S., \& Abarca, J. (2010). Time to prison return for offenders with serious mental illness released from prison a survival analysis. Criminal Justice and Behavior, 37(2), 175-187. doi:10.1177/0093854809354370

Costopoulos, J. S., Plewinski, A. M., Monaghan, P. L., \& Edkins, V. A. (2017). The impact of US Government assistance on recidivism. Criminal Behaviour and Mental Health. http://doi.org/10.1002/cbm.1997

Fazel, S., Buxrud, P., Ruchkin, V., \& Grann, M. (2010). Homicide in discharged patients with schizophrenia and other psychoses: A national case-control study. Schizophrenia Research, 123(2-3), 263-269. http://doi.org/10.1016/j.schres.2010.08.019
Fazel, S., \& Yu, R. (2011). Psychotic disorders and repeat offending: Systematic review and meta-analysis. Schizophrenia Bulletin, 37(4), 800-810. http://doi.org/10.1093/schbul/sbp135

Gendreau, P., Little, T., \& Goggin, C. (1996). a Meta-Analysis of the Predictors of Adult Offender Recidivism: What Works!*. Criminology, 34(4), 575-608. http://doi.org/10.1111/j.17459125.1996.tb01220.x

Grann, M., Danesh, J., \& Fazel, S. (2008). The association between psychiatric diagnosis and violent re-offending in adult offenders in the community. BMC Psychiatry, 8, 1-7. http://doi.org/10.1186/1471-244X-892

Graña, J. L., Garrido-Genovés, V., \& González, L. (2007). Evaluación de las características delictivas de menores infractores de la comunidad de Madrid y su influencia en la planificación del tratamiento. Psicopatología Clínica Legal Y Forense, 7, 7-18.

Graña, J.L (2012). Evaluación del riesgo de reincidencia delictiva en España. Madrid. Ministerio del interior.

Håkansson, A., \& Berglund, M. (2012). Risk factors for criminal recidivism - a prospective follow-up study in prisoners with substance abuse. BMC Psychiatry, 12. http://doi.org/10.1186/1471-244X-12-111

Hall, D. L., Miraglia, R. P., Lee, L.-W.G., Chard-Wierschem, D., Sawyer, D. (2012). Predictors of general and violent recidivism among SMI prisoners returning to communities in New York State. Journal of the American Academy of Psychiatry and the Law, 40 (2), 221-231. Recuperado de: http://www.jaapl.org/content/40/2/221.full.pdf + html

Hare, R. D. (2003). Hare Psychopathy Checklist-Revised, 2nd edition. Toronto, ON, Canada: Multi Health Systems. doi: 10.4135/9781412959537.n134 
Hilterman, E. y Andrés-Pueyo, A. (2005). HCR-20. Guía para la valoración de comportamientos violentos. Barcelona: Universidad de Barcelona

López-Barrachina, R., Lafuente, O., \& García J. L. (2007). Del mito de Narciso a los trastornos de la personalidad en las cárceles aragonesas: Una aproximación al perfil de estos desórdenes en las personas privadas de libertad. Revista Española de Sanidad Penitenciaria, $9(2)$, $28-40$ Recuperado http://www.sanipe.es/OJS/index.php/RESP/article/view/93

King, R., \& Elderbroom, B. (2014). Improving recidivism as a performance measure. Justice Policy Center Brief, (October).

Nakamura, K., \& Bucklen, K. B. (2014). Recidivism, redemption, and desistance: Understanding continuity and change in criminal offending and implications for interventions. Sociology Compass. http://doi.org/10.1111/soc4.12150

Pflueger, M. O., Franke, I., Graf, M., \& Hachtel, H. (2015). Predicting general criminal recidivism in mentally disordered offenders using a random forest approach. BMC Psychiatry, 15(1), 1-10. http://doi.org/10.1186/s12888-015-0447-4

Plattner, B., Steiner, H., The, S. S. L., Kraemer, H. C., Bauer, S. M., Kindler, J., ... Feucht, M. (2009). Sex-specific predictors of criminal recidivism in a representative sample of incarcerated youth. Comprehensive Psychiatry, 50(5), 400-407. http://doi.org/10.1016/j.comppsych.2008.09.014
Rodrígue, J. M. A., Gómez, J. L. G., Fernández, M. E. P., \& Reyes, A. B. (2013). Riesgo de violencia y psicopatía en distintas tipología delictivas: Un studio empírico. Behavioral Psychology / Psicología Conductual: Revista Internacional Clínica Y de La Salud, 21(2), 289-301. Retrieved from

http://search.proquest.com.proxy.library.carleton.ca/docview/151803 4420 ? account id $=9894$

Segeren, M., de Wit, M., Fassaert, T., \& Popma, A. (2017). Determinants of prisoners' perceived need for care in association with criminal recidivism. Journal of Forensic Psychiatry and Psychology, 28(4), 477-497. http://doi.org/10.1080/14789949.2017.1301527

Swogger, M. T., Walsh, Z., Christie, M., Priddy, B. M., \& Conner, K. R. (2015). Impulsive versus premeditated aggression in the prediction of violent criminal recidivism. Aggressive Behavior, 41(4), 346-352. http://doi.org/10.1002/ab.21549

Vicens, E., Tort, V., Dueñas R. M., Muro, A., Pérez-Arnau, F., Arroyo, J. M., Acín, E... \& Sardá, P. (2011). The prevalence of mental disorders in Spanish prisons. Criminal Behaviour and Mental Health, 21(5), 321-332. doi: $10.1002 / \mathrm{cbm} .815$

Yang, M., Wong, S. C. P., \& Coid, J. (2010). The efficacy of violence prediction: A meta-analytic comparison of nine risk assessment tools. Psychological Bulletin, 136(5), 740-767. http://doi.org/10.1037/a0020473

Zabala Baños, M. C. (2016). Prevalencia de trastornos mentales en prisión: análisis de la relación con delitos y reincidencia. Tesis 